\title{
The Bilingual Dictionary and Foreign Language Learning: Facts and Opinions
}

Gema Alcaraz Mármol

Universidad Católica de Murcia

Ángela Almela Sánchez-Lafuente

Universidad de Murcia

Received: 12 December 2011 / Accepted: 15 April 2013

ISSN: $1697-7467$

\begin{abstract}
Despite the eminently communicative approaches to FL, learners still feel the need to have almost immediate access to the meaning or form of foreign words. With this premise in mind, we have conducted the present study on the bilingual dictionary, being our goal twofold. Firstly, we compare the task where the dictionary is required with other three tasks where it is not used. Then, the results of the dictionary task are compared to the participants' opinion about the dictionary. Results suggest that the use of the dictionary is not as efficient as expected. Yet, a positive attitude towards this tool prevails among the best performers.
\end{abstract}

Keywords: Attitude, bilingual dictionary, Primary education, Secondary education, vocabulary learning.

Diccionarios bilingües y aprendizaje de lengua extranjera: hechos y opiniones

RESUMEN: A pesar del enfoque eminentemente comunicativo que impera en el aprendizaje de lenguas, los estudiantes siguen teniendo esa necesidad de acceder de manera casi inmediata a la forma o significado de las palabras en una segunda lengua. Bajo esta premisa se ha llevado a cabo este estudio sobre el uso del diccionario bilingüe, en el que se persigue un doble objetivo. Primero se compara el efecto sobre el aprendizaje léxico de una tarea con diccionario con otras de distinta índole. Tras ello, los resultados de la primera se comparan con las opiniones de los estudiantes acerca de esta herramienta. Los resultados sugieren que el uso del diccionario no es tan eficaz como se esperaba. No obstante, los participantes que mejor puntúan muestran una actitud positiva hacia esta herramienta.

Palabras clave: Actitud, adquisición léxica, diccionario bilingüe, educación primaria, educación secundaria.

\section{INTRODUCTION}

The dictionary has traditionally been a widely used tool by Foreign Language students, both in their self process of vocabulary acquisition and trying to understand a text. The reason is that vocabulary which is the main content of a dictionary can be considered «the 
building block of languages» (Schmitt, Schmitt, \& Clapham 2001: 53). That is why students carry dictionaries, and not grammar books, when they travel abroad (McLaughlin 1978).

However, the more recent approaches such as the Communicative method seem to have left this tool aside. The dictionary seems to have been replaced by other techniques. This tendency started around the late 70 s and $80 \mathrm{~s}$, when the prevalent view among educators was that L2 learners should consult a dictionary sparingly and only as a last resort (Carrell, Devine, \& Eskey 1988). Consequently, this lexical tool was replaced by inferring from context, a strategy which was thought to be more efficient and effective for dealing with unfamiliar vocabulary. Students are encouraged and presumably trained to infer the meaning of foreign words with the help of context. In fact, Hosenfeld (1984) prompts teachers to train learners in the use of guessing techniques, so that they can avoid the dictionary. Rubin (1975: 45) states that «the good language learner is a willing and accurate guesser».

Yet, Gardner (1993) warns that not all students learn the same way. If this is so, some very good students might prefer the use of the dictionary rather than guessing from context. What is more, Hosenfeld (1984) and Rubin (1975) do not contemplate what is called the beginner's paradox. It is estimated that vocabulary learning from context is only possible and reliable when the student understands between $95 \%$ and $98 \%$ of the text (Laufer 2005). This means that the learner must know at least from 3000 to 3500 words in order to be able to infer meaning in authentic non-specialized texts (Nation 1990). The beginner's paradox can be represented by a vicious circle. As the beginners' knowledge of the foreign language is very limited, it is difficult for them to learn new vocabulary from context. If they do not know enough vocabulary, they cannot infer meanings from context.

Despite the current repercussion of guessing in FL learning, still some authors keep on defending the role of the dictionary in L2 reading comprehension and vocabulary learning. Regarding the former, some studies (Luppescu \& Day 1993; Knight 1994; Hulstijn, Hollander, \& Greidanus 1996; Fraser 1997) show how dictionary use contribute positively to the attention to form-meaning connections, rehearsal and association with other types of knowledge. All these are cognitive processes required for vocabulary acquisition. In the study by Luppescu and Day (1993) students had to read a story which included 17 unknown words and had the help of a bilingual dictionary. After reading, they took a vocabulary test where they got high scores. This suggests that the dictionary use can have a positive effect on vocabulary acquisition. Knight (1994) also examined how the use of a bilingual dictionary may have an effect on vocabulary learning and L2 reading comprehension. Results revealed that the use of the dictionary favoured these two aspects. The negative point in the use of the dictionary was the reading rate. The dictionary users took more time to read the whole text.

In the same line, Hulstijn, Hollander and Greidanus (1996) found out that when a student looked up a word in the dictionary, their retention rate was higher than other reading conditions such as marginal glosses. Fraser (1997) goes one step further. She resorted to the think-aloud protocol to know how successful the use of a bilingual dictionary was. The author stated that a strategic combination guessing and dictionary use was the most effective way to deal with L2 reading comprehension. Results also revealed that consulting a dictionary was associated with substantial vocabulary learning. Songhao (1997) also remarks the 
positive effects of the dictionary use and how learners seem to have the need to confirm their guess and clarify their confusions with the dictionary.

A study by Cote and Tejedor (1998) reveals that the students may not be making an adequate use of the dictionary. The authors mention the "widespread ignorance» about this tool on the students' part. In fact, the survey that was done for this study pointed to lack of correspondence between the students' beliefs and reality. In other words, most students thought they were good at using a dictionary while they were not. It was observed that they did not pay attention to the dictionary entry on the whole, but just looked for the L1 equivalent. The authors comment on the initial negative attitude towards the dictionary when students were asked to use it. Everything changed when students were given some guidance. After instruction they admitted to have enjoyed the experience, and were eager to use the dictionary more often.

With these premises in mind, we have conducted the present study where both the objective side of the dictionary use its efficiency in vocabulary learning and the subjective side the students' opinions about it are dealt with. On the basis of what has been exposed above, this paper will present an overview of results pertaining to two issues: dictionary use and vocabulary learning and attitudes towards dictionary use in the FL classroom.

\section{Aim}

The aim of the present study is twofold. On the one hand, we compare the results of a task where the use of the dictionary is required with other three tasks where the dictionary is not used. On the other hand, the results of the dictionary task are compared with the participants' opinion about the dictionary and its use.

\section{Methodology}

\subsection{Participants}

The study was developed with participants of two educational levels: Primary and Secondary education. The reason for this is that it allowed a broader view on the situation, since it deals with the two main educational stages. Both groups comprised 28 learners each, which amounts to a total of 56. The Primary Education group belonged to a public school in the Region of Murcia and were taking their fifth year. At the moment of the study, they had received about 648 hours of instruction, thus their level could be considered to be Elementary.

The group of Secondary Education students attended their fourth year. They were also from the Region of Murcia. Given the number of hours they have been exposed to, they can be considered Low-Intermediate. The two groups spoke Spanish as their native language and could not speak any other foreign language except for English. 


\subsection{Materials and tasks}

\subsubsection{Words}

Each group worked with 18 words, though they were different in each case due to the age, the English level and the cognitive status. The words for the Primary Education group were selected from a graded reader called «A pretty face» by John Escott (2008). This book is written specifically for Elementary students of English as a Foreign Language. Six nouns, six adjectives and six verbs were randomly chosen for the study (see Table 1).

\section{Table 1. Target words in Primary Education.}

\begin{tabular}{|l|l|l|}
\hline Nouns & Verbs & Adjectives \\
\hline Actress & Believe & Amazed \\
\hline Costume & Follow & Difficult \\
\hline Desk & Hate & Free \\
\hline Interview & Hide & Funny \\
\hline Lie & Pay & Kind \\
\hline Movie & Refuse & Pretty \\
\hline
\end{tabular}

In the case of the Secondary Education students, we randomly selected 18 words from a list of not highly frequent terms (3k) for learners at a low-intermediate level. Similar to the other group, they belonged to the three main grammatical categories (see Table 2).

\section{Table 2. Target words in Secondary Education.}

\begin{tabular}{|l|l|l|}
\hline Nouns & Verbs & Adjectives \\
\hline Bargain & Blow & Dark \\
\hline Boss & Chase & Dirty \\
\hline Chess & Check & Empty \\
\hline Clerk & Fit & Guilty \\
\hline Flu & Fix & Healthy \\
\hline Leather & Flush & Lonely \\
\hline
\end{tabular}

\subsubsection{Vocabulary tasks}

The tasks entailed different levels of involvement load. They were designed within the framework of Hulstijn and Laufer's Involvement Load Hypothesis (2001), which suggests that the use of the dictionary in language tasks might influence the way in which new vocabulary is acquired. The origin of this proposition is to be found in the Depth of Processing Model (Craik \& Lockhart 1972). These authors stated that retention in long term memory depends on how deep information is processed during learning. Put another way, 
the information that is processed at a deep level stays in memory longer than that which goes through a shallower processing.

This initial approach to memory was expanded by Craik and Tulving some years later (1975). Whereas Craik and Lockhart presented three levels of processing (orthographic, acoustic and semantic), Craik and Tulving added the notion of elaboration to this model. That is to say, new information which is connected to information that already exists in memory gives place to more robust memory traces. However, there was a main criticism to this model, which points to the lack of encoding specificity. In other words, the Depth of Processing Model did not operationalize the degree of cognitive effort or elaboration.

Laufer and Hulstijn (2001) tried to operationalize the concept of elaboration and felt the need to transfer this concept to the field of L2 vocabulary. They proposed the construct of «involvement», and this was the beginning of their hypothesis; it implied that the higher the involvement load, the larger and the better the amount of L2 vocabulary acquired. Specifically, this construct is built upon cognitive and motivational aspects. The three components of «involvement» are need, search and assessment. The first one is embedded in the motivational dimension, whereas the other two are related to the cognitive dimension of the construct. Both need and evaluation are organized into three levels: 0 or none, 1 or moderate and 2 or strong. Level 1 of need is given when the learner is required to learn the word by an external agent, for instance, the teacher. In level 1 of evaluation, the word is compared with other words in a specific context. The strong level of need and evaluation refers to the learner's own initiative to learn the word in the first case, and the free use of the word by the learner, respectively. Search only accounts for two levels: 0 or none and 1 or presence (Table 3 ).

Table 3. Degrees of involvement.

\begin{tabular}{|l|l|l|}
\hline Components & \multicolumn{1}{|c|}{$\begin{array}{c}\text { Degrees of } \\
\text { Involvement }\end{array}$} & \multicolumn{1}{|c|}{ Definition } \\
\hline \multirow{3}{*}{ Need } & Index 0 (none) & The learner does not feel the need to learn the word \\
\cline { 2 - 4 } & Index 1 (moderate) & The learner is required to learn the word \\
\cline { 2 - 4 } & Index 2 (strong) & The learner decides the learn the word \\
\hline \multirow{2}{*}{ Search } & Index 0 (absence) & $\begin{array}{l}\text { The learner does not look for the meaning or form of the } \\
\text { word with a lexical instrument }\end{array}$ \\
\cline { 2 - 4 } & Index 1 (existence) & The meaning and form of the word are found by the learner \\
\cline { 2 - 4 } & Index 0 (none) & The word is not compared with any other word \\
\cline { 2 - 4 } & Index 1 (moderate) & The word is compared with other words in the provided \\
\cline { 2 - 4 } & Index 2 (strong) & $\begin{array}{l}\text { The word is compared with other words self-provided context } \\
\text { (the learner's mental lexicon) }\end{array}$ \\
\hline
\end{tabular}

According to the parameters shown in Table 3, we have designed four tasks with different degree of involvement: 
- Task 1: Reading comprehension with marginal glosses

Students are asked to read a series of short paragraphs in English and answer a true/ false questionnaire about the paragraphs. In each of these paragraphs there is one of the target words selected for the study. These words appear in bold so as to highlight their presence. At the end of the paragraphs students can find the meaning of the target word between brackets. The content of these paragraphs is constituted by vocabulary that is understandable for the students, so that they can concentrate on the target word. According to Hulstijn and Laufer, task 1 contains a degree of involvement 1, as it includes moderate need (1) and no search or assessment.

- Task 2: Reading comprehension and fill-in the gaps

This second activity contains the same paragraphs of task 1 . However, students find a gap instead of the target words in the paragraphs. The task consists of filling in the gaps with the target words, which are alphabetically listed at the end of the task, together with their Spanish translation. In addition to the target words, seven distractors were included. The degree of involvement in task 2 includes moderate need (1) and moderate assessment (1) and no search.

- Task 3: Writing with marginal glosses

Task 3 consists of writing sentences with each of the target words. These words are listed in alphabetical order, together with their Spanish translation. Students are asked to write a sentence which shows that they have understood the meaning of the target word. This task presents a degree of involvement 3 , as it includes moderate need (1), strong assessment (2), but still no search.

- Task 4: Writing and dictionary use

Similar to task 3 , in task 4 students are asked to write meaningful sentences. However, this time students do not find the words translated into Spanish. It is the students who have to search the meaning of the targets words into a dictionary. All students are provided with the same dictionary. It was the most basic version of the Collins Pocket Plus English-Spanish dictionary. We decided to use a very basic dictionary so as to avoid the students' possible confusion if they found several meanings for the same word. It is important to remark that students had already had experience with dictionary searching. Therefore, the fact that they had to use a dictionary did not imply an additional degree of difficulty. According to the ILH, this task contains a degree of involvement 4, as it includes moderate need (1), strong assessment (2) and, for the first time in this study, search (1).

It is worth noting that each activity was distributed to a different group of students in each level. Thus, each task was performed by two groups, one of the groups consisting of seven Primary education students and the other one of seven Secondary education students. 


\subsubsection{Vocabulary tests}

Three weeks before the study was carried out, all students did a pre-test in order to know whether they already knew the target words. The object of the test was to translate the target words into Spanish.

After the eight groups of students had done their corresponding task, all students in each level did the same productive and receptive vocabulary tests. First, the productive tests were distributed. Students were asked to translate the Spanish target words into English. In the second place, the receptive tests were done by students, who had to translate the English target words into Spanish. The order of distribution is not arbitrary: the productive tests are considered to require more cognitive effort than the receptive tests. Therefore, the receptive tests were distributed in the second place so as to avoid that students could glean hints from these tests onto the productive ones.

\subsubsection{Data analysis}

In order to compare the degree of acquisition (dependent variable) in the eight groups of learners, the parametric test of the analysis of variance or ANOVA has been run. In this case, the independent variable is the degree of involvement in the tasks. The ANOVA was completed with a post-hoc analysis (HDS Tukey) for the identification of the possible significant inter-group differences. According to the research norm in Linguistics, differences are considered significant when $\mathrm{p}<0.05$.

On the other hand, the results of the dictionary task have been compared with the participants' opinion about dictionary use by means of a Pearson correlation coefficient, so as to detect any correlation between both variables.

\section{RESUlts}

As can be seen in Table 4, the critical level associated to $\mathrm{F}$ is much higher than .05 both in the receptive (.597) and the productive test (.431). Consequently, we can assume that all the compared means present no significant differences between them. Put another way, the four tasks applied in the study do not make a difference in the students' degree of vocabulary acquisition, running counter to the Involvement Load Hypothesis.

Table 4. Overall ANOVA receptive and productive tests.

\begin{tabular}{|ll|c|c|c|c|c|}
\hline & $\begin{array}{c}\text { Sum of } \\
\text { squares }\end{array}$ & df & $\begin{array}{c}\text { Quadratic } \\
\text { mean }\end{array}$ & F & Sig. \\
\hline $\mathrm{R}$ & Inter-groups & 56.714 & 3 & 18.905 & .634 & .597 \\
& Intra-groups & 1551.000 & 52 & 29.827 & & \\
& Total & 1607.714 & 55 & & & \\
& Inter-groups & 91.857 & 3 & 30.619 & .935 & .431 \\
& Intra-groups & 1703.571 & 52 & 32.761 & & \\
& Total & 1795.429 & 55 & & & \\
\hline
\end{tabular}


However, the considerable significance found among the four groups of Primary Education is worth noticing (see Table 5):

Table 5. ANOVA receptive and productive tests for Primary Education students.

ANOVA

\begin{tabular}{|ll|c|c|c|c|c|}
\hline & $\begin{array}{c}\text { Sum of } \\
\text { squares }\end{array}$ & df & $\begin{array}{c}\text { Quadratic } \\
\text { mean }\end{array}$ & F & Sig. \\
\hline $\mathrm{R}$ & Inter-groups & 144.857 & 3 & 48.286 & 27.592 & .000 \\
& Intra-groups & 42.000 & 24 & 1.750 & & \\
& Total & 186.857 & 27 & & & \\
$\mathrm{P}$ & Inter-groups & 152.714 & 3 & 50.905 & 34.208 & .000 \\
& Intra-groups & 35.714 & 24 & 1.488 & & \\
& Total & 188.429 & 27 & & & \\
\hline
\end{tabular}

The results from the post-hoc analysis reflect significant differences among the scores of most groups indeed (Table 6). As regards the receptive test, it can be observed how all the groups differ except for the second one and the fourth one, which means in practice that both groups of participants have a similar level of receptive lexical knowledge. On the other hand, groups 1 and 3 substantially differ, both between them and with the remaining groups. The former produces the expected performance, but the latter achieves the best score, despite the fact that it is not the group with the higher degree of involvement.

When it comes to the productive test, groups 1 and 2 score similarly; thus the post-hoc test does not detect significant differences among them. The third group scores markedly better than the fourth one, which parallels the results from the receptive test.

Table 6. Tukey HSD for Primary Education students.

\begin{tabular}{|c|c|c|c|c|c|c|c|}
\hline \multirow{2}{*}{\multicolumn{2}{|c|}{$\begin{array}{l}\text { Dependent variable } \\
\text { (J) mode }\end{array}$}} & \multirow[b]{2}{*}{ mode } & \multirow{3}{*}{$\begin{array}{c}\begin{array}{c}\text { Means } \\
\text { difference } \\
(\mathrm{I}-\mathrm{J})\end{array} \\
-3.429^{*}\end{array}$} & \multirow{3}{*}{$\begin{array}{r}\begin{array}{c}\text { Typical } \\
\text { error }\end{array} \\
.707 \\
\end{array}$} & \multirow{3}{*}{$\begin{array}{l}\text { Sig. } \\
.000\end{array}$} & \multicolumn{2}{|c|}{$\begin{array}{c}\text { Confidence interval } \\
95 \%\end{array}$} \\
\hline & & & & & & $\begin{array}{l}\text { Limit } \\
\text { inferior }\end{array}$ & $\begin{array}{l}\text { Limit } \\
\text { superior }\end{array}$ \\
\hline \multirow[t]{9}{*}{$\mathrm{R}$} & \multirow[t]{3}{*}{1} & 2 & & & & -5.38 & -1.48 \\
\hline & & 3 & $-6.429 *$ & .707 & .000 & -8.38 & -4.48 \\
\hline & & 4 & $-3.286^{*}$ & .707 & .001 & -5.24 & -1.34 \\
\hline & \multirow[t]{3}{*}{2} & \multirow{3}{*}{$\begin{array}{l}1 \\
3 \\
4\end{array}$} & $3.429 *$ & .707 & .000 & 1.48 & 5.38 \\
\hline & & & $-3.000 *$ & .707 & .002 & -4.95 & -1.05 \\
\hline & & & .143 & .707 & .997 & -1.81 & 2.09 \\
\hline & \multirow[t]{3}{*}{3} & \multirow{3}{*}{$\begin{array}{l}1 \\
2 \\
4\end{array}$} & $6.429 *$ & .707 & .000 & 4.48 & 8.38 \\
\hline & & & $3.000 *$ & .707 & .002 & 1.05 & 4.95 \\
\hline & & & $3.143^{*}$ & .707 & .001 & 1.19 & 5.09 \\
\hline
\end{tabular}


Table 6. Tukey HSD for Primary Education students (Cont.).

\begin{tabular}{|c|c|c|c|c|c|c|c|}
\hline \multirow{2}{*}{\multicolumn{2}{|c|}{$\begin{array}{l}\text { Dependent variable } \\
\text { (J) mode }\end{array}$}} & \multirow[b]{2}{*}{ node } & \multirow{3}{*}{$\begin{array}{c}\begin{array}{c}\text { Means } \\
\text { difference } \\
(\mathrm{I}-\mathrm{J})\end{array} \\
3.286^{*}\end{array}$} & \multirow{3}{*}{$\begin{array}{l}\begin{array}{c}\text { Typical } \\
\text { error }\end{array} \\
.707\end{array}$} & \multirow{3}{*}{$\begin{array}{l}\text { Sig. } \\
.001\end{array}$} & \multicolumn{2}{|c|}{$\begin{array}{c}\text { Confidence interval } \\
95 \%\end{array}$} \\
\hline & & & & & & $\begin{array}{l}\text { Limit } \\
\text { inferior }\end{array}$ & $\begin{array}{l}\text { Limit } \\
\text { superior }\end{array}$ \\
\hline & \multirow[t]{3}{*}{4} & \multirow[t]{3}{*}{1} & & & & 1.34 & 5.24 \\
\hline & & & .143 & .707 & .997 & -2.09 & 1.81 \\
\hline & & & $3.143^{*}$ & .707 & .001 & -5.09 & -1.19 \\
\hline \multirow[t]{12}{*}{$\mathrm{P}$} & \multirow[t]{3}{*}{1} & \multirow{3}{*}{$\begin{array}{l}2 \\
3 \\
4\end{array}$} & -1.000 & .652 & .434 & -2.80 & .80 \\
\hline & & & $-6.000 *$ & .652 & .000 & -7.80 & -4.20 \\
\hline & & & $-3.571 *$ & .652 & .000 & -5.37 & -1.77 \\
\hline & \multirow[t]{3}{*}{2} & \multirow{3}{*}{$\begin{array}{l}1 \\
3\end{array}$} & 1.000 & .652 & .434 & -.80 & 2.80 \\
\hline & & & $-5.000 *$ & .652 & .000 & -6.80 & -3.20 \\
\hline & & & $-2.571^{*}$ & .652 & .003 & -4.37 & -.77 \\
\hline & \multirow[t]{3}{*}{3} & \multirow{3}{*}{$\begin{array}{l}1 \\
2 \\
4\end{array}$} & $6.000 *$ & .652 & .000 & 4.20 & 7.80 \\
\hline & & & $5.000 *$ & .652 & .000 & 3.20 & 6.80 \\
\hline & & & $2.429 *$ & .652 & .005 & .63 & 4.23 \\
\hline & \multirow[t]{3}{*}{4} & \multirow{3}{*}{$\begin{array}{l}1 \\
2 \\
3\end{array}$} & $3.571 *$ & .652 & .000 & 1.77 & 5.37 \\
\hline & & & $2.571 *$ & .652 & .003 & .77 & 4.37 \\
\hline & & & $-2.429 *$ & .652 & .005 & -4.23 & -.63 \\
\hline
\end{tabular}

*Means difference is significant at .05 level.

As in the case of the overall results, the bilateral significance associated to $\mathrm{F}$ is much higher than .05 both in the receptive (.733) and the productive tests (.815) of the Secondary Education students (Table 7). Thus, it can be stated that there are no significant differences between them.

Table 7. ANOVA receptive and productive tests for Secondary Education students.

\section{ANOVA}

\begin{tabular}{|ll|c|c|c|c|c|}
\hline & $\begin{array}{c}\text { Sum of } \\
\text { squares }\end{array}$ & df & $\begin{array}{c}\text { Quadratic } \\
\text { mean }\end{array}$ & F & Sig. \\
\hline $\mathrm{R}$ & Inter-groups & 30.000 & 3 & 10.000 & .430 & .733 \\
& Intra-groups & 557.714 & 24 & 23.238 & & \\
& Total & 587.714 & 27 & & & .815 \\
$\mathrm{P}$ & Inter-groups & 24.429 & 3 & 8.143 & .314 & \\
& Intra-groups & 621.429 & 24 & 25.893 & & \\
& Total & 645.857 & 27 & & & \\
\hline
\end{tabular}


As regards the comparison between the results of the dictionary task and the participants' opinion about dictionary use, the overall Pearson correlation coefficient is indeed significant (see Table 8). This means in practice that, in general terms, the success in the task by virtue of dictionary use may lead the user to think highly of this tool.

Table 8. Overall Pearson correlation coefficients.

\begin{tabular}{|ll|c|c|}
\hline & & punct_dictio & opinion \\
\hline punct_dictio & Pearson correlation & 1 & $.552\left(^{*}\right)$ \\
& Sig. (bilateral) & & .041 \\
& $\mathrm{~N}$ & 14 & 14 \\
\multirow{5}{*}{ opinion } & Pearson correlation & $.552\left(^{*}\right)$ & 1 \\
& Sig. (bilateral) & .041 & \\
& $\mathrm{~N}$ & 14 & 14 \\
\hline
\end{tabular}

* Correlations is significant at 0,05 level (bilateral).

\section{Discussion}

As can be seen above, results point to a different behavior as regards task performance on the part of the two student levels. Whereas Primary Education students show significant differences in the four tasks, no significant differences were found in Secondary Education students. We observed that the dictionary did not seem to have the positive effect on acquisition that we expected, and as it was predicted by the ILH.

One possible reason for that is the lack of training in dictionary use. In the case of Primary Education students, the dictionary seemed to be conceived more as an obstacle than as a helping tool. While carrying out the dictionary task, students spent too much time in looking up the words. They also felt frustrated and anxious because not always would they be able to find them. Some of the participants in this task even asked to change their group.

In the same line scores for Secondary Education students were not very optimistic either. Although there were not important differences from the other three tasks, students dealing with the dictionary task did not perform better in the vocabulary tests. We observed that the other groups felt more comfortable with the other tasks. In addition, many members of the group working with the dictionary were unable to find the correct option in case they found a polysemous word. This fact reflects that problems were beyond the dictionary use, and that other linguistic weaknesses could be in the root of the dictionary misuse.

However, and curiously enough, and despite drawbacks, when we asked students about the use of the dictionary, both Primary and Secondary Education groups in general showed a positive attitude towards this tool. What is more, even though results were not the expected ones, it was found that those who showed a positive attitude towards the dictionary performed better in that task than those who did not. 
Students think that the dictionary can be a helpful tool, as long as you know how to use it. However, it becomes a double-edge sword if we cannot make an adequate use. In fact, the misuse or no use of the bilingual dictionary can lead to a negative attitude towards this tool, which at the same time can have a negative effect on acquisition as we can infer from the results of our study.

Given this situation, we can pose two questions: why this reticence on the part of students to using this tool and how can we change this situation. As regards the first question, part of the origin of this unwillingness might be found in the concept that some people have of the Communicative approach for language teaching. That is to say, given some aspects of the Communicative method it can be understood as avoiding translation to the L1. Consequently, the use of the bilingual dictionary within this methodological framework is barely considered.

This runs somehow counter to real situations that normally occur in the classroom. One of the most common questions posed by students during a L2 lesson concerns the meaning of some L2 word. If our students have an elementary L2 level, it is very difficult to solve the problem of L2 meaning through the L2 itself. This is what is called the «beginners paradox». That is to say, as the beginners' knowledge of the foreign language is very limited, it is difficult for them to learn to solve problems of meaning through the use of the L2. The L2 level of elementary students is too low for them to sort out their understanding problems with just the L2.

As for the second question, an introduction of a training program is suggested. This program should make students aware of linguistic phenomena such as polysemy and homonymy. It should also call the students' attention on morphology and other types of information that is found in dictionary entries, and finally it should present the context as an ally rather than an enemy. That is to say, the context can offer information about the word, which can be used when looked up in the dictionary. In this line, it is also important the role of the teacher in transmitting a positive attitude towards the bilingual dictionary, both implicitly and explicitly. She should highlight the value of this tool, leaving aside too radical postures.

Finally, the use of the bilingual dictionary can also contribute to the students' autonomy. In other words, the dictionary reinforces the learners' ability to monitor their own learning process. They are able to solve some of their L2 problems on their own without resorting to the teacher. This fact is highly positive as it motivates students, encouraging them to take the bridles of their own L2 learning process.

\section{FinAl REMARKS}

The present study deals with the students' use of the bilingual dictionary at two levels: Primary and Secondary education. Contrary to what it is suggested by the ILH, those working with a dictionary task got worse results in vocabulary tests than those who carried out other type of task. Yet, positive attitude towards the bilingual dictionary on the part of some students had an effect on vocabulary acquisition. 
Therefore, the main action to be taken is to introduce and reinforce the use of the bilingual dictionary at all levels. It is important for students to become familiarized with this tool. Otherwise, their lack of familiarity might lead to a negative attitude towards it, which might negatively affect acquisition.

\section{REFERENCES}

Carrell, P., Devine J. and Eskey, D. (eds.) (1988). Interactive Approaches to Second Language Reading. Cambridge: Cambridge University Press.

Cote, M. and Tejedor, C. (1998). «La enseñanza de vocabulario y el uso del diccionario», in Encuentro. Revista de Investigación e Innovación en la clase de idiomas, 10: 26-35.

Craik, F. and Lockhart, R. (1972). «Levels of processing: A framework for memory research», in Journal of verbal learning and verbal behaviour, 11: 671-84.

Craik, F.I.M. and Tulving, E. (1975). «Depth of processing and the retention of words in episodic memory», in Journal of Experimental Psychology: General, 104, 268-294.

Escott, J. (2008). A pretty face. London: Dominoes Publishers.

Fraser, C. (1997). «The role of consulting a dictionary in reading and vocabulary learning», in Canadian Journal of Applied Linguistics, 2, 2: 73-89.

Gardner, H. (1993). Multiple Intelligences: The Theory in Practice. New York: Basic Books.

Hosenfeld, C. (1984). «Case studies of ninth grade readers», in J.C. Alderson and A. H. Urquhart (eds.), Reading in a foreign language. London: Longman, 231-44.

Hulstijn, J. and Laufer, B. (2001). «Some empirical evidence for the involvement Load Hypothesis in vocabulary acquisition», in Language Learning, 51, 3: 539-58.

Hulstijn, J., Hollander, M. and Greidanus, T. (1996). «Incidental vocabulary learning by advanced foreign language students: the influence of marginal glosses, dictionary use, and reoccurrence of unknown words», in The Modern Language Journal, 80, 3: 327-39.

Knight, S. (1994). «Dictionary use while reading: The effects on comprehension and vocabulary acquisition for students of different verbal abilities», in The Modern Language Journal, 78, 3: 285-99.

Laufer, B and Hulstijn, J. (2001). «Incidental vocabulary acquisition in a second language: the construct of task-induced involvement», in Applied Linguistics, 22: 1-26.

Laufer, B. (2005). «Lexical Frequency profiles: From Monte Carlo to the Real World. A response to Meara», in Applied Linguistics, 26, 4: 582-88.

Luppescu, S. and Day, R. (1993). «Reading dictionaries and vocabulary learning» in Language Learning, 43: 26387.

McLaughlin, B. (1978). «The monitor model: Some methodological considerations», in Language Learning, 28: 309-32.

Nation, I.S.P. (1990). Teaching and learning vocabulary. Boston, MA: Heinle and Heinle. 
Rubin, J. (1975). «What the 'good language learner' can teach us», in TESOL Quarterly, 9: 41-51.

Schmitt, N., Schmitt, D. and Clapham, C. (2001). «Developing and exploring the behaviour of two new versions of the Vocabulary Levels Test», in Language Testing, 18, 1: 55-88.

Songhao, L. (1997). «Dictionary use as a way of learning vocabulary in SLA: A preliminary study», in Directions: Journal of Educational Studies, 36, 1: 82-99. 